\title{
Jean-Jacques Glassner
}

Des dieux, des scribes et des savants

Circulation des idées et transmission des écrits en Mésopotamie

Il existe un paradoxe, s'agissant du registre du savoir en Mésopotamie ancienne: celui-ci relève de la sphère du secret et, pourtant, il fait l'objet d'une ample diffusion et large transmission, par les voies de l'oralité aussi bien que de l'écriture. Partant, le rayonnement de la culture intellectuelle babylonienne est grand dans l'ensemble du monde connu. Tel est le résultat de l'effort constant de familles de scribes dont certaines perdurent pendant plusieurs siècles, et au sein desquelles le savoir est transmis de génération en génération. Leurs membres copient et recopient inlassablement les ouvrages anciens comme les compositions les plus récentes. Ils se montrent très actifs dans le cadre de bibliothèques privées ou institutionnelles.

Gods, scribes and scholars

The circulation of knowledge and the transmission of written work in Mesopotamia

There is an apparent Mesopotamian paradox: knowledge belonged to a secret lore, but was nevertheless widely transmitted by oral and written means. Moreover, the influence of Babylonian intellectual culture made itself felt over the whole known world. This was primarily do to the constant effort of families of scribes, some of which lasting for several centuries. From one generation to the other, their members were copying all kind of ancient as well as recent compositions. Their work took place mainly in private and institutional libraries.

\section{Christian Jacob}

"La table et le cercle»

Sociabilités savantes sous I'Empire romain

Plutarque, Aulu-Gelle et Athénée de Naucratis sont trois auteurs représentatifs de la littérature savante d'époque impériale. Au-delà de la différence de leurs projets, ils partagent un trait commun: ils mettent en scène les pratiques et le statut même du savoir lettré, sous la forme de dialogues réunissant des interlocuteurs occasionnels ou appartenant aux mêmes cercles sociaux. Cette étude voudrait prendre au sérieux ce choix d'exposition narratif et théâtral pour des textes de savoir et explorer les rituels de la sociabilité savante à Rome et en Grèce (conversation, visites, banquets), aux deux premiers siècles de notre ère, ainsi que les enjeux d'une forme d'activité intellectuelle qui repose sur la confrontation dialectique des points de vue et l'exploration ludique d'une mémoire culturelle partagée. 
"Banquets and social circles"

Learned communities in Roman Empire

Plutarch, Aulus Gellius and Athenaeus of Naucratis are three representative writers of the extant scholarly literature during the first centuries of the Roman Empire. Despite the differences in the issues which they addressed, they share a common feature: they stage the practices and the status of scholarship, and they use the dialogue form involving various characters who at times belong to the same social circles. This paper discusses the choice of such a narrative and a theatrical framework for scholarly texts, and examines the social rituals of learned communities in Rome and Greece (conversations, visits, banquets) as well as the deeper meanings of scholarly practices based on the dialectical comparison of intellectual standpoints and the playful exploration of a shared cultural memory.

\section{Alfred-Louis de Prémare}

Wahb b. Munabbih, une figure singulière du premier islam

Wahb b. Munabbih est souvent cité comme transmetteur de «traditions israélites » destinées à expliquer les textes coraniques concernant les prophètes anciens. Il nous faut cependant aller au-delà de ce cadre convenu, et reconsidérer les informations diverses disponibles sur Wahb (origines familiales, curriculum vitae et fonctions, activités intellectuelles, relations avec ses pairs et avec les autorités politiques, etc.), en vue de mieux le situer non seulement dans le milieu naissant des clercs musulmans, mais encore dans le contexte général, politique et culturel, de l'histoire ommeyade.

\section{Wahb b. Munabbih}

An unusual character in the nascent milieu of the Muslim scholars

Wahb b. Munabbih is very often quoted as transmitter of "Israelite traditions" to provide explanations for the Quranic passages concerning the ancient prophets. But we must go beyond this conventional scope, and reconsider the varied informations about Wahb (family's origins, curriculum vitae and functions, intellectual activities, relationship with colleagues and politic authorities, etc.) in order to place him not only in the nascent milieu of the Muslim scholars, but also in the general politic and cultural context of the Umayyad history.

\section{Cezary Galewicz}

L'Anyōnyam

Un rituel de récitation des textes sacrés au Kerala

Transmettre les textes sacrés en Inde a toujours été l'affaire des communautés de lettrés. Dans le cas du Veda, longtemps préservé sous une forme orale seulement, il s'agissait de faire preuve d'une grande dextérité en matière de connaissances textuelles, nourries d'une mémorisation à la fois individuelle et collective. L'écrit n'était pas considéré comme un médium assez sûr pour préserver le savoir sacré, entraînant très tôt la croyance magique dans le fait que le Veda - le savoir sacré par excellence - devait être récité sans aucune erreur ou faute de prononciation. L'article examine les méthodes mnémotechniques sophistiquées destinées, sous forme d'une compétition, à assurer une transmission parfaite du Veda, ici dans le cas de la communauté Nambudiri du Kerala. 


\section{Anyōnyam \\ Ritual recitation of sacred knowledge in Kerala}

Transmitting sacred texts in India has always been an affair of elite communities of learned professionals. In the case of the Veda, which had been for a long time preserved orally, it was rather mastering dexterity in textual competence through professionally enhanced skills of individual and collective memory. Script was judged as too unreliable a medium for safe preservation; this must have been influenced an early belief: Veda, the sacred knowledge par excellence, had to be properly recited and any error or miss-pronunciation eradicated. The paper examines the sophisticated mnemotechics developed to secure a perfect transmission of the Veda, in the case of the Nambudiri community challenging in competitions of recitation.

\section{Maria Ferretti}

Mémoires divisées

Résistance et guerre aux civils en Italie

L'article présente les recherches conduites en Italie au cours de la dernière décennie sur ce que l'on a appelé «la mémoire divisée de la Résistance». Acte fondateur et légitimant de la République italienne née après la guerre, la Résistance fut figée dans une image d'Épinal qui célébrait l'unité du peuple italien, partisans et civils confondus, dans la lutte de libération nationale contre l'occupant nazi et le fascisme. Or, cette image lisse a été remise en cause dans les années 1990: on a commencé, d'une part, à montrer comment la mémoire publique de la Résistance avait été construite, et, d'autre part, à restituer la complexité de la mémoire populaire, elle-même divisée de l'intérieur, en raison des blessures profondes laissées par la violence des massacres nazis. Ceux-ci ont en effet provoqué une fracture entre civils et partisans, considérés dans certains cas comme responsables, par leurs actions, des représailles des occupants.

\section{Divided memories \\ Resistance and war against civilians in Italy}

This text presents the latest studies on what has been called the divided memory of the Italian Resistance. The Resistance, which founded and legitimized the Italian Republic after the war, was congealed into a myth celebrating the unity of the Italian people - partisans and civilians - fighting together to liberate the Nation from Nazi occupier and Fascism. This smooth image began to be questioned in the 1990s. First, these studies showed how the collective memory of the Resistance had taken shape; then they strove to reassess a popular memory internally divided because of the profound wounds caused by Nazi massacres. Such violence estranged civilians from partisans, whose actions were deemed responsible, in some instances, for the Occupier's retaliations.

\section{Gilles Bataillon \\ De Sandino aux contras \\ Formes et pratiques de la guerre au Nicaragua}

Comment interpréter les guerres civiles - Somoza/sandinistes; sandinsistes/contras - dont le Nicaragua a été le théâtre de 1978 à 1987? Alors que la plupart des analyses mettent l'accent sur les «blocages» socio-politiques internes et le rôle des interventions étrangères, 
on s'efforce ici d'analyser ces guerres en les réinscrivant dans un continuum avec les autres affrontements armés qui ont marqué le $\mathrm{Xx}^{\mathrm{e}}$ siècle nicaraguayen. L'ancrage de ces deux guerres dans un «temps long» de la violence nicaraguayenne permet ensuite de comprendre comment, tout au long du siècle, la violence fut une modalité d'action légitime et codifiée et comment celle-ci permit tout à la fois l'apparition de nouveaux acteurs sociopolitiques et, ce faisant, leur accès légitime à des ressources économiques. On décrit ensuite quelles furent les modalités de structuration interne de ces acteurs, puis la «culture politique» dans laquelle s'inscrivit cette succession d'actions guerrières. On s'interroge pour finir sur le basculement qui s'est fait jour lors de la fin de l'affrontement contras/sandinistes et lors du mandat de Violeta Barrios de Chamorro.

From Sandino to contras

War forms and practice in Nicaragua

How are we to interpret the civil wars - Somoza vs. Sandinistas; Sandinistas vs. Somoza - which have struck Nicaragua from 1978 to 1987? While most analyses put the stress on internal sociopolitical "deadlocks" and the part played by foreign interventions, the aim here is to reinstate these wars within the succession of armed conflicts which have plagued Nicaragua in the 20th century. Rooting these two wars in Nicaragua's "long term" cycle of violence enables to understand how violence could become, throughout the 20th century, a legitimate and codified way of action and how it made it possible for new socio-political actors to emerge and to gain legitimate access to economic resources. The article then moves on to describe how these actors as well as the "political culture" of this series of war episodes was internally structured. Finally, the article looks into the changes which have taken place since the end of the contras/sandinistas confrontation and during Violeta Barrios de Chamorro's mandate. 